\title{
ОПЛАТА ТРУДА В РЕСПУБЛИКЕ БЕЛАРУСЬ: СОЦИАЛЬНО-ЭКОНОМИЧЕСКАЯ ЭФФЕКТИВНОСТЬ
}

\author{
Т.Н. Долинина*
}

В статье разграничены категории «заработная плата» и «оплата труда». Определены функции оплаты труда как процесса. На основе статистических и социологических индикаторов дана оценка реализации функций оплаты труда в национальной экономике Беларуси. Выявлены социальные и экономические проблемы оплаты труда. Сделаны выводы о необходимости реформирования национальной модели оплаты труда.

Ключевые слова: оплата труда, заработная плата, функции оплаты труда, реформирование оплаты труда.

JEL-классификация: J31.

DOI: $10.46782 / 1818-4510-2020-2-60-78$

Материал поступил 20.02.2020 2.

Основным драйвером инновационного экономического роста является трудовая мотивация, которая должна способствовать поддержанию высокой конкурентоспособности страны в современной глобальной экономике. Однако в Концепции национальной безопасности Республики Беларусь ${ }^{1}$ отражено, что к числу внутренних угроз национальной безопасности относится недостаточная мотивация работников к эффективному труду, отмечаемая на фоне снижения численности трудоспособного населения.

Национальная стратегия устойчивого социально-экономического развития Республики Беларусь на период до 2030 года к числу приоритетных задач относит разработку механизмов мотивации труда, что невозможно без кардинальных системных и качественных преобразований в сфере оплаты труда, обеспечивающих ее значительную модернизацию. Между тем реформирование отечественной модели оплаты труда, предпринятое с 1 января 2020 г., обнажило всю глубину кризиса социальнотрудовой сферы, сложность трансформаци-

1 Указ Президента Республики Беларусь от 9 ноября 2010 г. № 575 «Об утверждении Концепции национальной безопасности Республики Беларусь». онных процессов в этой области, их обусловленность историческим контекстом формирования отечественных институтов управления оплатой труда, объективными закономерностями и общемировыми тенденциями развития, а также особенностями функционирования экономики Республики Беларусь на современном этапе. Это указывает на целесообразность исследований, которые дадут возможность определить направления последующей институциональной трансформации отечественной модели оплаты труда.

\section{Оплата труда: \\ функции в национальной экономике}

Оплата труда по содержанию - это отношения по поводу оплаты работодателями труда наемных работников; по форме - процесс формирования заработной платы (совокупность процедур, связанных с установлением условий оплаты труда работников и их соблюдением), выполняющий ряд функций, направленных на обеспечение конкурентоспособности хозяйственной системы. Результатом процесса оплаты труда выступает заработная пла$m a$, которая по содержанию представляет собой объем средств, выплачиваемый на-

* Долинина Татьяна Николаевна (tdolinina@mail.ru), кандидат экономических наук, Белорусский государственный технологический университет (г. Минск, Беларусь). 
нимателем работнику за его труд; по форме - это денежный поток определенной интенсивности, выполняющий ряд функций в экономическом кругообороте 2 .

Оплата труда как процесс выполняет следующие функции в национальной экономике:

воспроизводственную (формирование заработной платы, достаточной для удовлетворения физических и духовных потребностей работников различных профессионально-квалификационных групп и членов их семей на необходимом для их воспроизводства уровне);

компенсирующую (обеспечение денежной компенсации неблагоприятных условий труда и режима работы);

регулирующую (оптимизация расстановки и закрепление работников в соответствии с их квалификацией);

стимулирующую (формирование у работников мотивации к труду);

социальную (поддержание достойной заработной платы и социальной справедливости);

функцию поддержания конкурентоспособности хозяйственной системы (обеспечение конкурентного уровня заработной платы при минимизации затрат на оплату труда).

Реализация каждой из функций осуществляется на уровне субъектов хозяйствования. При этом функции оплаты труда не только взаимосвязаны, но и ранжированы в представленном выше порядке. Эффективная реализация каждой последующей функции становится возможной лишь при условии выполнения предыдущей. В этой связи базовой функцией оплаты труда выступает воспроизводственная, степень реализации которой может стать как условием, так и препятствием для выполнения всех последующих функций. Эффективное исполнение оплатой труда своих функций обеспечивает максимальный для существующих условий уровень заработной платы.

Функциональный подход к раскрытию содержания категории «оплата труда» создает возможности для диагностики соци-

${ }^{2}$ Долинина Т.Н. 2019. Институциональные модели управления оплатой труда. Ч. 1. Минск: БГТУ. С. 87. альных и экономических проблем оплаты труда в отечественной экономике и поиска путей их решения.

\section{Воспроизводственная функция оплаты труда}

В экономике Беларуси 96\% занятых наемные работники. Большинство из них не имеет других источников дохода, кроме заработной платы. В 2000 г. среднемесячная заработная плата белорусов была ниже двух бюджетов прожиточного минимума трудоспособного населения $\left(\right.$ БП $\left.\mathrm{M}_{\mathrm{T}}\right)-$ $184 \%$, в 2005 г. составляла около трех БПМ т (292\%), в 2010 г. впервые превысила его четырехкратное значение - 413\%, в 2013 г. составляла 448\%, а в 2019 г. после снижения в период 2014-2016 гг. подросла до 437\%. В ноябре 2019 г. 1,8\% работников получали заработную плату ниже БПМ Динамика соотношения среднемесячной заработной платы со среднедушевым минимальным потребительским бюджетом в значительной мере повторяет динамику предыдущего соотношения. Несмотря на интенсивный рост этого показателя (в 2013 г. он в 2,5 раза превышал уровень 2000 г.), уровень 1990 г. (299\%) он превысил лишь только в 2013 г. (315\%), после чего упал до 301\% в 2019 г. (рис. 1).

В условиях невысокой заработной платы работники нередко заинтересованы в удлинении продолжительности рабочей недели. Статистика свидетельствует о том, что в 2018 г. из числа занятого населения в возрасте 15-74 лет 4,5\% фактически отрабатывали от 41 до 50 час. в неделю, 2,7\% - свыше 48 час. в неделю, а $23,2 \%$ к тому же были заняты в личном подсобном хозяйстве производством продукции, используемой для собственного потребления. При этом доля неформальной занятости по данным официальной статистики составила 8,2\% (табл. 1). Вероятно, она частично включает и тех работников, для которых неформальная занятость является дополнительной.

Распространенность дополнительной занятости позволяют изучать социологические опросы. Социологи констатируют наличие слоев населения, способных в неблагоприятных социально-экономических условиях к самостоятельному решению на- 


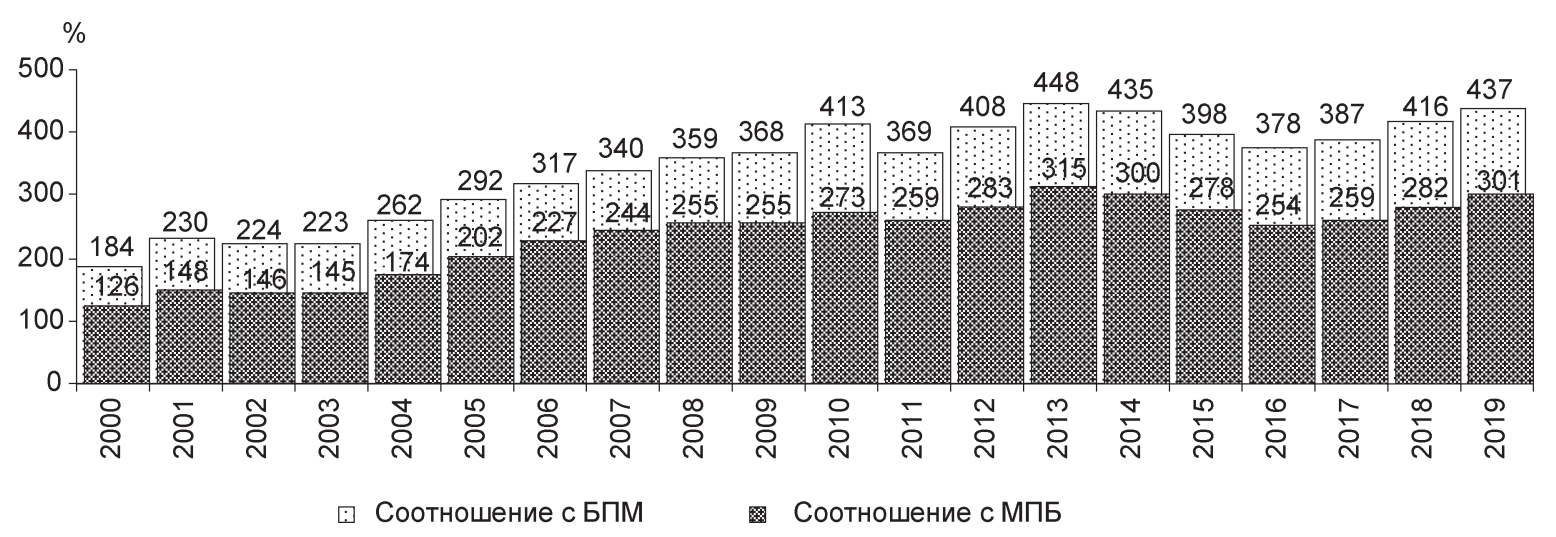

Рис. 1. Динамика покупательной способности заработной платы в Республике Беларусь

Источник. Авторская разработка на основе: Статистический ежегодник Республики Беларусь, 2012: стат. сборник. 2012. Минск: Национальный статистический комитет Республики Беларусь. С. 176; Статистический ежегодник Республики Беларусь, 2019: стат. сборник. 2019. Минск: Национальный статистический комитет Республики Беларусь. С. 155, 158; Номинальная начисленная среднемесячная заработная плата за 2019 год. URL: https://www.belstat.gov.by/ofitsialnaya-statistika/realny-sector-ekonomiki/stoimost-rabochey-sily/godovyedannye/nominalnaya-nachislennaya-srednemesyachnaya-zarabotnaya-plata-po-oblastyam-i-g-minsku/

сущных проблем - почти каждый четвертый работник в стране имеет вторичную (дополнительную) занятость (табл. 2). В качестве главной причины, побуждающей иметь вторичную занятость, большинство респондентов указывают низкий уровень заработной платы на основной работе.

Вторичная занятость, с одной стороны, позволяет увеличить доходы работников и их семей, с другой стороны, считается, что она ухудшает отношение работников к труду, уменьшая их интерес к основной работе, вследствие чего снижается эффективность трудовой деятельности. Кроме того, у работников не остается дос- таточно свободного времени для отдыха, досуга и удовлетворения социокультурных потребностей, что негативно сказывается на состоянии их здоровья.

Здоровье населения в трудоспособном возрасте заслуживает особого внимания, поскольку этот контингент является движущей силой экономики и характеризуется тенденцией к абсолютному сокращению его численности. Несмотря на то, что численность врачей-специалистов и других медицинских работников в Беларуси в расчете на душу населения постоянно растет, острыми остаются проблемы высокой, в том числе хронической, заболеваемости трудо-

Таблица 1

Отдельные индикаторы достойного труда в Республике Беларусь

\begin{tabular}{|c|c|c|c|c|c|c|c|}
\hline \multirow{3}{*}{ Год } & \multicolumn{2}{|c|}{$\begin{array}{c}\text { Среднее количество } \\
\text { фактически } \\
\text { отработанных часов в } \\
\text { неделю на одного } \\
\text { занятого } \\
\end{array}$} & \multicolumn{4}{|c|}{$\begin{array}{c}\text { Удельный вес занятого населения (15-74 лет) в общей } \\
\text { численности занятого населения данной возрастной группы, } \\
\%\end{array}$} & \multirow{3}{*}{$\begin{array}{c}\text { Доля } \\
\text { нефор- } \\
\text { мальной } \\
\text { занятости } \\
\text { в несель- } \\
\text { скохозяй- } \\
\text { ственных } \\
\text { секторах, } \\
\text { \% }\end{array}$} \\
\hline & \multirow{2}{*}{$\begin{array}{c}\text { на } \\
\text { основной и } \\
\text { дополни- } \\
\text { тельной } \\
\text { работе }\end{array}$} & \multirow[t]{2}{*}{$\begin{array}{c}\text { на дополни- } \\
\text { тельной } \\
\text { работе }\end{array}$} & \multicolumn{2}{|c|}{$\begin{array}{c}\text { по фактически } \\
\text { отработанному } \\
\text { количеству рабочих часов } \\
\text { в неделю на основной и } \\
\text { дополнительной работе, час. }\end{array}$} & \multirow{2}{*}{$\begin{array}{c}\text { фактически } \\
\text { работающего } \\
\text { избыточное } \\
\text { время (более } \\
48 \text { час. в } \\
\text { неделю) }\end{array}$} & \multirow{2}{*}{$\begin{array}{c}\text { занятого в личном } \\
\text { подсобном } \\
\text { хозяйстве } \\
\text { производством } \\
\text { продукции, } \\
\text { используемой для } \\
\text { собственного } \\
\text { потребления }\end{array}$} & \\
\hline & & & $31-40$ & $41-50$ & & & \\
\hline 2016 & 35,0 & 0,3 & 78,1 & 3,8 & 2,3 & 23,1 & 7,4 \\
\hline 2017 & 35,3 & 0,2 & 78,0 & 4,2 & 2,7 & 23,2 & 8,3 \\
\hline 2018 & 35,7 & - & 78,6 & 4,5 & 3,0 & - & 8,2 \\
\hline
\end{tabular}

Источник. Авторская разработка на основе: Перечень ключевых показателей системы индикаторов достойного труда. URL: https://www.belstat.gov.by/upload-belstat/upload-belstat-word/Oficial_statistika/ Perech_pokaz_DT.doc 
Распространенность вторичной (дополнительной) занятости в Республике Беларусь, \% от числа ответивших

\begin{tabular}{|l|c|c|c|c|}
\hline Формы дополнительной занятости & 2012 & 2013 & 2014 & 2015 \\
\hline Регулярная дополнительная работа по основному виду деятельности & 3,0 & 4,0 & 3,4 & 2,2 \\
Регулярная дополнительная работа в другом месте & 4,9 & 4,1 & 5,3 & 5,2 \\
Случайные приработки, заработки & 16,3 & 14,5 & 16,5 & 15,4 \\
Дополнительная занятость отсутствует & 75,8 & 77,4 & 74,8 & 77,2 \\
\hline Итого & 100,0 & 100,0 & 100,0 & 100,0 \\
\hline
\end{tabular}

Источник. Авторская разработка на основе (Соколова, 2015. С. 51).

способных граждан. Стабильно высоким остается число зарегистрированных случаев заболеваний с впервые установленным диагнозом и численность лиц трудоспособного возраста, впервые признанных инвалидами. При этом в стране растет доля населения, субъективно оценивающего состо- яние своего здоровья как плохое. Если по данным выборочного обследования домашних хозяйств по уровню жизни в 2010 г. на плохое состояние здоровья указали 16\% населения трудоспособного возраста (в зависимости от возрастной группы), то в 2019 г. - уже 2-8\% (табл. 3, 4).

\section{Динамика заболеваемости населения в Республике Беларусь}

Таблица 3

\begin{tabular}{|c|c|c|c|c|c|}
\hline \multirow[t]{2}{*}{ Год } & \multirow{2}{*}{$\begin{array}{c}\text { Зарегистрировано } \\
\text { случаев заболеваний с } \\
\text { диагнозом, } \\
\text { установленным впервые } \\
\text { в жизни, на } 100000 \text { чел. } \\
\text { населения }\end{array}$} & \multirow{2}{*}{$\begin{array}{c}\text { Численность лиц, } \\
\text { впервые признанных } \\
\text { инвалидами в возрасте от } \\
18 \text { лет и до окончания } \\
\text { трудоспособного } \\
\text { возраста }\end{array}$} & \multicolumn{3}{|c|}{$\begin{array}{c}\text { Субъективная оценка населением } \\
\text { состояния своего здоровья*, } \\
\text { \% от численности населения } \\
\text { в возрасте } 16 \text { лет и старше }\end{array}$} \\
\hline & & & хорошее & удовлетворительное & плохое \\
\hline 2010 & 87445 & 19276 & 32,3 & 61,5 & 6,2 \\
\hline 2011 & 89744 & 21011 & 32,5 & 61,4 & 6,1 \\
\hline 2012 & 82935 & 21890 & 30,9 & 61,1 & 8,0 \\
\hline 2013 & 84214 & 21955 & 29,9 & 62,1 & 8,0 \\
\hline 2014 & 79262 & 20576 & 27,8 & 64,5 & 7,7 \\
\hline 2015 & 81637 & 20960 & 27,0 & 63,1 & 9,9 \\
\hline 2016 & 83260 & 19950 & 27,6 & 63,3 & 9,1 \\
\hline 2017 & 85876 & 20229 & 27,6 & 62,8 & 9,6 \\
\hline 2018 & 85586 & 20358 & 27,6 & 63,1 & 9,3 \\
\hline 2019 & - & - & 27,5 & 64,0 & 8,5 \\
\hline
\end{tabular}

* По данным выборочного обследования домашних хозяйств по уровню жизни на начало года.

Источник. Авторская разработка на основе: Статистический ежегодник Республики Беларусь, 2019: стат. сборник. 2019. Минск: Национальный статистический комитет Республики Беларусь. С. 134, 142; Социальное положение и уровень жизни населения Республики Беларусь, 2012: стат. сборник. 2012. Минск: Национальный статистический комитет Республики Беларусь. С. 248-249; Социальное положение и уровень жизни населения Республики Беларусь, 2019: стат. сборник. 2019. Минск: Национальный статистический комитет Республики Беларусь. С. $203-204$.

Таблица 4

Субъективная оценка населением Республики Беларусь состояния своего здоровья, на начало года, \% к итогу

\begin{tabular}{|c|l|c|c|c|c|c|}
\hline \multirow{2}{*}{ Год } & \multicolumn{5}{|c|}{ Состояние здоровья } & \multicolumn{5}{|c|}{ Возрас, лет } \\
\cline { 3 - 7 } & & $16-29$ & $30-39$ & $40-49$ & $50-59$ & 60 и старше \\
\hline \multirow{3}{*}{2010} & хорошее & 58,7 & 48,7 & 28,5 & 18,8 & - \\
\cline { 2 - 7 } & удовлетворительное & 40,2 & 50,3 & 69,2 & 75,0 & - \\
\cline { 2 - 7 } & плохое & 1,1 & 1,0 & 2,3 & 6,2 & - \\
\hline \multirow{2}{*}{2019} & хорошее & 54,2 & 45,7 & 32,0 & 15,5 & 5,4 \\
\cline { 2 - 7 } & удовлетворительное & 43,2 & 51,1 & 64,1 & 76,8 & 75,0 \\
\cline { 2 - 7 } & плохое & 2,6 & 3,2 & 3,9 & 7,7 & 19,6 \\
\hline
\end{tabular}

Источник. Авторская разработка на основе: Социальное положение и уровень жизни населения Республики Беларусь, 2012: стат. сборник. 2012. Минск: Национальный статистический комитет Республики Беларусь. С. 248-249; Социальное положение и уровень жизни населения Республики Беларусь, 2019: стат. сборник. 2019. Минск: Национальный статистический комитет Республики Беларусь. С. 203-204. 
По оценкам ВОЗ, неинфекционные заболевания «стоят» экономике Беларуси 5,4\% ВВП. Общий экономический ущерб от них в 13 раз превышает затраты на их лечение. Четыре основные группы неинфекционных заболеваний - сердечно-сосудистые, диабет, хронические болезни легких и онкология обходятся экономике Беларуси около 4,7 млрд руб. в год. Из них менее 330 млн руб. составляют затраты государства на лечение этих заболеваний, остальные 4,3 млрд руб. - это непрямые расходы, связанные с преждевременной смертностью, временной нетрудоспособностью и снижением производительности труда при формальном присутствии работника на работе 3 .

Уровень трудовых доходов, налагая «отпечаток» на здоровье занятого населения и членов их семей, тем самым участвует в формировании важнейших демографических тенденций. В последние десятилетия в стране наблюдаются негативные тенденции в части воспроизводства населения. Для современной Беларуси характерна низкая продолжительность жизни по сравнению с развитыми странами, невысокая рождаемость, сверхсмертность, ведущие к депопуляции населения (табл. 5).

3 URL: https://apps.who.int/iris/bitstream/handle/ 10665/112824/WHO_HIS_HIA_14.1_rus.pdf;jsessionid=1B20 EF6AA9E82EBC19A236221D4BA897? ?sequence $=8$
Простого воспроизводства населения в стране не было с 1980 г. - для простого замещения поколений суммарный коэффициент рождаемости (среднее число рождений у одной женщины за ее жизнь) должен равняться 2,14-2,15, а не 1,4-1,7, как в последние годы (Крупейченко, 2016). В то же время социологи отмечают, что белорусы хотят иметь детей больше, чем могут себе позволить.

Снижение рождаемости протекает на фоне высоких показателей смертности. В соответствии со стандартами ВОЗ, смертность, превышающая 10 чел. на 1000 населения, квалифицируется как сверхсмертность. В Беларуси почти каждый пятый умирает в трудоспособном возрасте, а показатели уровня смертности среди мужчин в возрасте 15-60 лет в 3-4,5 раза выше, чем в странах Европейского союза. Большинство случаев смерти происходит от болезней системы кровообращения, растет число умерших от новообразований, высока смертность от внешних причин: несчастных случаев, дорожно-транспортных происшествий, случайных утоплений, отравлений алкоголем и др. (табл. 6).

Таким образом, как прямые, так и косвенные индикаторы указывают на невыполнение воспроизводственной функции оплаты труда в должной мере, что ослабляет предпосылки для реализации всех последующих функций.

Показатели воспроизводства населения в Республике Беларусь

\begin{tabular}{|c|c|c|c|c|c|c|}
\hline Год & $\begin{array}{c}\text { Численность } \\
\text { населения на начало } \\
\text { года, тыс. чел. }\end{array}$ & $\begin{array}{c}\text { Суммарный } \\
\text { коэффициент } \\
\text { рождаемости }\end{array}$ & $\begin{array}{c}\text { Родившихся } \\
\text { на 1000 чел. } \\
\text { населения }\end{array}$ & $\begin{array}{c}\text { Умерших } \\
\text { на 1000 чел. } \\
\text { населения }\end{array}$ & $\begin{array}{c}\text { Коэффициент } \\
\text { депопуляции } \\
\text { населения }\end{array}$ & $\begin{array}{c}\text { Коэффициент } \\
\text { ижденческой } \\
\text { нагрузки }\end{array}$ \\
\hline 1990 & 10189 & 1,913 & 14,0 & 10,8 & 0,8 & 0,44 \\
\hline 1995 & 10210 & 1,406 & 9,9 & 13,1 & 1,3 & 0,42 \\
\hline 2000 & 10003 & 1,317 & 9,4 & 13,5 & 1,4 & 0,36 \\
\hline 2005 & 9697 & 1,252 & 9,4 & 14,7 & 1,6 & 0,28 \\
\hline 2010 & 9500 & 1,494 & 11,4 & 14,4 & 1,3 & 0,26 \\
\hline 2011 & 9481 & 1,515 & 11,5 & 14,3 & 1,2 & 0,26 \\
\hline 2012 & 9465 & 1,620 & 12,2 & 13,4 & 1,1 & 0,27 \\
\hline 2013 & 9464 & 1,668 & 12,5 & 13,2 & 1,1 & 0,27 \\
\hline 2014 & 9468 & 1,696 & 12,5 & 12,8 & 1,0 & 0,28 \\
\hline 2015 & 9481 & 1,724 & 12,5 & 12,6 & 1,0 & 0,29 \\
\hline 2016 & 9498 & 1,733 & 12,4 & 12,6 & 1,0 & 0,30 \\
\hline 2017 & 9505 & 1,541 & 10,8 & 12,6 & 1,2 & 0,31 \\
\hline 2018 & 9492 & 1,448 & 9,9 & 12,7 & 1,3 & 0,31 \\
\hline
\end{tabular}

Источник. Авторская разработка на основе: Статистический ежегодник Республики Беларусь, 2019: стат. сборник. 2019. Минск: Национальный статистический комитет Республики Беларусь. С. 134, 142; Демографический ежегодник Республики Беларусь, 2019: стат. сборник. 2019. Минск: Национальный статистический комитет Республики Беларусь. С. 23. 
Оплата труда в Республике Беларусь: социально-экономическая эффективность

Таблица 6

Показатели смертности населения в трудоспособном возрасте в Республике Беларусь, число умерших на 100000 чел. населения

\begin{tabular}{|c|c|c|c|c|c|c|}
\hline \multirow{2}{*}{ Год } & \multirow{2}{*}{$\begin{array}{c}\text { Умерло от } \\
\text { всех причин }\end{array}$} & $\begin{array}{c}\text { от болезней } \\
\text { системы } \\
\text { кровообращения }\end{array}$ & $\begin{array}{c}\text { от } \\
\text { новообразования }\end{array}$ & $\begin{array}{c}\text { от болезней } \\
\text { органов } \\
\text { пищеварения }\end{array}$ & $\begin{array}{c}\text { от прочих } \\
\text { болезней }\end{array}$ & $\begin{array}{c}\text { от внешних } \\
\text { причин }\end{array}$ \\
\hline 1990 & 429,6 & 135,2 & 97,0 & 12,3 & 23,0 & 133,6 \\
\hline 1995 & 562,8 & 178,5 & 98,3 & 18,2 & 30,7 & 194,8 \\
\hline 2000 & 529,3 & 156,6 & 86,6 & 21,5 & 30,0 & 197,1 \\
\hline 2005 & 592,9 & 179,8 & 83,3 & 34,1 & 41,3 & 211,0 \\
\hline 2010 & 550,5 & 175,4 & 85,3 & 41,5 & 36,7 & 174,9 \\
\hline 2011 & 561,6 & 182,2 & 86,6 & 46,3 & 37,6 & 165,3 \\
\hline 2012 & 472,0 & 153,5 & 84,6 & 33,3 & 26,7 & 141,8 \\
\hline 2013 & 452,3 & 149,2 & 82,5 & 31,9 & 26,8 & 129,5 \\
\hline 2014 & 435,8 & 146,8 & 85,3 & 29,7 & 24,8 & 120,7 \\
\hline 2015 & 405,4 & 139,7 & 84,9 & 25,2 & 22,5 & 106,9 \\
\hline 2016 & 392,2 & 136,3 & 84,1 & 23,9 & 21,9 & 100,6 \\
\hline 2017 & 387,8 & 136,7 & 86,4 & 22,4 & 21,6 & 96,3 \\
\hline 2018 & 407,0 & 146,8 & 89,2 & 25,9 & 30,0 & 95,6 \\
\hline
\end{tabular}

Источник. Авторская разработка на основе: Статистический ежегодник Республики Беларусь, 2019: стат. сборник. 2019. Минск: Национальный статистический комитет Республики Беларусь. С. 134, 142; Демографический ежегодник Республики Беларусь, 2019: стат. сборник. 2019. Минск: Национальный статистический комитет Республики Беларусь. С. 23.

\section{Компенсирующая функция оплать труда}

В условиях неполного выполнения воспроизводственной функции выплаты компенсирующего характера могут быть недостаточными для того, чтобы поддержать реализацию воспроизводственной функции, а затем обеспечить компенсацию неблагоприятных производственных факторов. Кроме того, наниматели нередко предпочитают выплачивать компенсации за работу в неблагоприятных условиях труда, чем затрачивать значительные средства на их улучшение, а работники готовы работать в этих условиях ради получения доплат к заработной плате, что косвенно подтверждает неполную реализацию воспроизводственной функции оплаты труда (Кляузе, Сечко, 2015).

Между тем ухудшение здоровья населения в значительной мере происходит в трудоспособном возрасте и связано это как с накоплением эндогенных заболеваний, так и с экзогенным воздействием (производственный травматизм, профессиональные заболевания). Статистика свидетельствует о постепенном сокращении численности работников, занятых на рабочих местах с вредными и (или) опасными условиями труда, а также работников, занятых тяжелым физическим и напряженным трудом (табл. 7).

Улучшение условий труда сопровождалось сокращением объемов компенсаций по условиям труда. Численность работников, занятых на рабочих местах с вредными и (или) опасными условиями труда сократилась с 20,6 чел. на 100 занятых в 2011 г. до 19,1 чел. в 2018 г., т. е. на 1,5 процентных пунктов (п. п.); численность работников, занятых тяжелым физическим и напряженным трудом - на 2,5 и 1,5 п. п. соответственно. Это привело к заметному сокращению численности работников, пользующихся хотя бы одним из видов компенсаций по условиям труда с 26,2 чел. на 100 занятых в 2011 г. до 17,9 чел. в 2018 г., в том числе имеющих право на оплату труда в повышенном размере с 904,1 до 652,7 тыс. чел. (табл. 8).

На фоне отмеченных позитивных тенденций противоречивой оказывается статистика профессиональной заболеваемости и производственного травматизма. Профессиональная заболеваемость сокращается гораздо меньшими темпами, чем численность работников, имеющих право на оплату труда в повышенном размере в связи с неблагоприятными условиями труда. Это указывает на недостаточность мер по компенсации неблагоприятного влияния производственных факторов ${ }^{4}$.

${ }^{4}$ Мотивация профессиональной деятельности государственных служащих Республики Беларусь: информационно-аналитическая записка по результатам социологического исследования. 2019. Академия управления при Президенте Республики Беларусь НИИ теории и практики государственного управлении. Минск. $31 \mathrm{c}$. 
Динамика численности работников с неблагоприятными условиями труда в Республике Беларусь, тыс. чел.

\begin{tabular}{|c|c|c|c|c|c|c}
\hline \multirow{2}{*}{ Год } & $\begin{array}{c}\text { Занятые на рабочих местах с } \\
\text { вредными и (или)опасными } \\
\text { условияи труда }\end{array}$ & \multicolumn{2}{|c|}{$\begin{array}{c}\text { Занятые тяжелым физическим } \\
\text { трудом }\end{array}$} & \multicolumn{2}{|}{$\begin{array}{c}\text { Занятые напряженным } \\
\text { трудом }\end{array}$} \\
\cline { 2 - 7 } & всего & на 100 занятых & всего & на 100 занятых & всего & на 100 занятых \\
\hline 2011 & 964,1 & 20,6 & 481,0 & 10,3 & 233,8 & 5,0 \\
\hline 2012 & 1032,4 & 22,4 & 405,4 & 8,8 & 273,6 & 5,9 \\
\hline 2013 & 1035,4 & 22,6 & 411,2 & 9,0 & 213,7 & 4,7 \\
\hline 2014 & 1010,6 & 22,2 & 405,7 & 8,9 & 199,2 & 4,4 \\
\hline 2015 & 939,6 & 20,9 & 372,1 & 8,3 & 177,3 & 3,9 \\
\hline 2016 & 935,2 & 21,2 & 392,6 & 8,9 & 178,7 & 4,1 \\
\hline 2017 & 899,0 & 20,6 & 366,0 & 8,4 & 166,2 & 3,8 \\
\hline 2018 & 827,1 & 19,1 & 340,1 & 7,8 & 152,3 & 3,5 \\
\hline
\end{tabular}

Источник. Авторская разработка на основе: Труд и занятость в Республике Беларусь, 2018: стат. сборник. 2018. Минск: Национальный статистический комитет Республики Беларусь. С. 178; Перечень ключевых показателей системы индикаторов достойного труда. URL: https://www.belstat.gov.by/upload-belstat/upload-belstat-word/ Oficial_statistika/Perech_pokaz_DT.doc

Вследствие усиления мер по охране труда в организациях производственный травматизм в стране до недавнего времени постепенно сокращался, однако при этом наблюдался заметный рост числа человеко-дней нетрудоспособности в расчете на одного потерпевшего на производстве, что может быть связано с неполным отражением несчастных случаев, не имеющих тяжких последствий на производстве. Между тем в 2018-2019 гг. число погибших или травмированных на производстве существенно выросло (табл. 9).

Потери рабочего времени от несчастных случаев на производстве в 2018 г. со- ставили 73,2 тыс. чел.-дн., что эквивалентно полной годовой занятости более чем 300 работников (в 2017 г. - 64,4 тыс. чел.-дн.). В этой связи в 2018 г. Министерство труда и социальной защиты анонсировало внедрение в Республике Беларусь с 2019 г. Концепции нулевого травматизма (Vision Zero), разработанной Международной ассоциацией социального обеспечения (MАСО). Концепция подразумевает, что несчастные случаи на производстве связаны не только с безопасностью и гигиеной труда, но и благополучием работника, к ключевым факторам которого следует отнести и размер получаемой заработной пла-

Таблица 8

\section{Динамика численности работников, пользующихся компенсациями} по условиям труда в Республике Беларусь

\begin{tabular}{|c|c|c|c|c|c|c|c|}
\hline \multirow{3}{*}{ Год } & \multirow{2}{*}{\multicolumn{2}{|c|}{$\begin{array}{c}\text { Численность работников, } \\
\text { пользующихся хотя бы одним } \\
\text { из видов компенсаций по } \\
\text { условиям труда }\end{array}$}} & \multicolumn{5}{|c|}{ Из них работники, которым предоставляется право, тыс. чел. } \\
\hline & & & \multirow{2}{*}{$\begin{array}{l}\text { на } \\
\text { дополни- } \\
\text { тельный } \\
\text { отпуск }\end{array}$} & \multirow{2}{*}{$\begin{array}{c}\text { на сокращенную } \\
\text { продолжительность } \\
\text { рабочего времени }\end{array}$} & \multirow{2}{*}{$\begin{array}{c}\text { на бесплатное } \\
\text { обеспечение } \\
\text { лечебно- } \\
\text { профилакти- } \\
\text { ческим } \\
\text { питанием }\end{array}$} & \multirow{2}{*}{$\begin{array}{c}\text { на бесплатное } \\
\text { обеспечение } \\
\text { молоком или } \\
\text { равноценными } \\
\text { пищевыми } \\
\text { продуктами }\end{array}$} & \multirow{2}{*}{$\begin{array}{c}\text { на оплату } \\
\text { труда в } \\
\text { повышенном } \\
\text { размере }\end{array}$} \\
\hline & $\begin{array}{c}\text { всего, } \\
\text { тыс. чел. }\end{array}$ & $\begin{array}{c}\text { \% от среднего- } \\
\text { довой численности } \\
\text { населения, заня- } \\
\text { того в экономике }\end{array}$ & & & & & \\
\hline 2011 & 1140,6 & 26,2 & 1046,5 & 87,0 & 9,3 & 451,3 & 904,1 \\
\hline 2012 & 1082,7 & 24,6 & 1029,1 & 92,1 & 9,3 & 412,4 & 891,7 \\
\hline 2013 & 1006,9 & 22,4 & 954,7 & 83,9 & 9,0 & 386,3 & 855,6 \\
\hline 2014 & 972,8 & 21,4 & 938,6 & 83,5 & 9,3 & 369,0 & 834,6 \\
\hline 2015 & 896,0 & 19,6 & 866,5 & 79,0 & 6,4 & 327,6 & 755,8 \\
\hline 2016 & 885,0 & 19,2 & 870,0 & 78,4 & 8,9 & 312,9 & 722,1 \\
\hline 2017 & 832,2 & 17,7 & 816,4 & 88,7 & 8,0 & 293,5 & 707,7 \\
\hline 2018 & 777,0 & 17,9 & 771,3 & 70,0 & 7,1 & 268,4 & 652,7 \\
\hline
\end{tabular}

Источник. Авторская разработка на основе: Труд и занятость в Республике Беларусь, 2018: стат. сборник. 2018. Минск: Национальный статистический комитет Республики Беларусь. С. 178; Перечень ключевых показателей системы индикаторов достойного труда. URL: https://www.belstat.gov.by/upload-belstat/upload-belstatword/Oficial_statistika/Perech_pokaz_DT.doc 
Динамика профессиональной заболеваемости и производственного травматизма в Республике Беларусь

\begin{tabular}{|c|c|c|c|c|c|c|}
\hline \multirow{2}{*}{ Год } & \multicolumn{2}{|c|}{$\begin{array}{c}\text { Работники с впервые } \\
\text { установленным } \\
\text { профессиональным } \\
\text { заболеванием, чел. }\end{array}$} & $\begin{array}{c}\text { Потерпевшие при несчастных } \\
\text { случаях на производсте с утратой } \\
\text { трудоспособности на один рабочий } \\
\text { день и более и со смертельным } \\
\text { исходом, чел. }\end{array}$ & $\begin{array}{c}\text { Число человеко-дней } \\
\text { нетрудоспособности у } \\
\text { потерпевших на } \\
\text { производстве }\end{array}$ \\
\cline { 2 - 7 } & всего & на 1000 занятых & всего & на 1000 занятых & всего, тыс. & на одного \\
\hline 2011 & 123 & 0,026 & 2349 & 0,501 & 94,6 & 40,3 \\
\hline 2012 & 97 & 0,021 & 2079 & 0,451 & 81,9 & 39,4 \\
\hline 2013 & 105 & 0,023 & 2001 & 0,437 & 79,5 & 43,1 \\
\hline 2014 & 91 & 0,020 & 1833 & 0,403 & 69,9 & 43,4 \\
\hline 2015 & 93 & 0,021 & 1524 & 0,339 & 67,6 & 45,8 \\
\hline 2016 & 97 & 0,022 & 1476 & 0,335 & 64,4 & 46,3 \\
\hline 2017 & 84 & 0,019 & 1390 & 0,319 & 67,3 & 43,8 \\
\hline 2018 & 72 & 0,017 & 1670 & 0,385 & 79,4 & 44,3 \\
\hline 2019 & - & - & 1793 & 0,408 & \\
\hline
\end{tabular}

Источник. Авторская разработка на основе: Травматизм на производстве. URL: https://www.belstat.gov.by/ ofitsialnaya-statistika/solialnaya-sfera/trud/godovye-dannye/travmatizm-na-proizvodstve/; Перечень ключевых показателей системы индикаторов достойного труда. URL: https://www.belstat.gov.by/upload-belstat/upload-belstat-word/ Oficial_statistika/Perech_pokaz_DT.doc

ты. Между тем данные Института социологии НАН Беларуси показывают, что в декабре 2018 г. каждый шестой работник не был удовлетворен условиями труда и только 9\% были удовлетворены получаемой заработной платой.

Таким образом, статистические и социологические индикаторы указывают на слабое выполнение компенсирующей функции оплаты труда. Неполное выполнение воспроизводственной и компенсирующей функций создает препятствия для эффективной реализации регулирующей функции.

\section{Регулирующая функция оплаты труда}

К конкурентным преимуществам Беларуси принято относить один из самых высоких в мире уровень образованности населения, высокую квалификацию работников (в особенности в таких отраслях, как автомобилестроение, тракторное и сельскохозяйственное машиностроение, оптика, радиоэлектроника, точное приборостроение, программирование) и относительно низкую стоимость трудовых ресурсов (Дайнеко, 2015). Согласно «Докладу о человеческом развитии 2019» ООН Беларусь занимает 30-е место в мире по индексу уровня образования 5 . При этом проблемой белорусского рынка труда является наличие значитель-

\footnotetext{
${ }^{5}$ URL: http://hdr.undp.org/en/2019-report/download
}

ного числа вакансий и безработных одновременно, что свидетельствует о дисбалансе спроса и предложения рабочей силы по профессионально-квалификационному составу, препятствующем рациональному использованию человеческого потенциала страны. Анализ конъюнктуры рынка труда показывает, что наблюдается избыток предложения по должностям служащих, преобладает спрос на рабочие профессии, существует острая нехватка специалистов по ряду позиций. Наиболее востребованными кадрами на рынке труда являются врачи и медсестры, специалисты строительного и сельскохозяйственного профиля, квалифицированные рабочие практически всех массовых профессий. Среди служащих отмечается дефицит инженеров, технологов, программистов, спросом пользуются специалисты сельскохозяйственного производства. Одновременно статистика показывает, что менее 63\% работников выполняют работу, соответствующую их квалификации, у $17,7 \%$ - работа ниже имеющейся квалификации, у 15,9\% - такого же уровня квалификации, но не связана с полученным образованием (табл. 10).

Причинами дисбалансов на рынке труда являются не только несоответствие объемов и структуры спроса и предложения рабочей силы и неспособность рыночного механизма в краткосрочном периоде реагировать на изменяющиеся требования к 
Таблица 10

Занятое население по уровню образования и соответствию квалификации выполняемой работе в Республике Беларусь в 2016 г., \%

\begin{tabular}{|l|c|c|c|c|c|}
\hline \multirow{2}{*}{ Уровень образования } & \multirow{2}{*}{ Всего } & \multicolumn{4}{|c|}{ В том числе выполняемая работа } \\
\cline { 3 - 6 } & $\begin{array}{c}\text { соответствует } \\
\text { квалификации }\end{array}$ & $\begin{array}{c}\text { ниже } \\
\text { квалификации }\end{array}$ & $\begin{array}{c}\text { выше } \\
\text { квалификации }\end{array}$ & $\begin{array}{c}\text { одинаковы, но } \\
\text { не связаны }\end{array}$ \\
\hline $\begin{array}{l}\text { Высшее } \\
\text { Среднее специальное }\end{array}$ & 100,0 & 68,2 & 16,6 & 1,9 & 13,3 \\
Профессионально- & 100,0 & 52,6 & 29,4 & 3,2 & 14,8 \\
техническое & 100,0 & 54,7 & 17,1 & 3,5 & 24,7 \\
Общее среднее & 100,0 & 79,3 & 4,8 & 8,2 & 7,7 \\
Общее базовое & 100,0 & 82,7 & 3,5 & 10,3 & 3,4 \\
\hline Всего & 100,0 & 62,7 & 17,7 & 3,7 & 15,9 \\
\hline
\end{tabular}

Источник. Авторская разработка на основе: Труд и занятость в Республике Беларусь, 2018: стат. сборник. 2018. Минск: Национальный статистический комитет Республики Беларусь. С. 41.

квалификации кадров, отсутствие действенного и эффективного государственного регулирования подготовки требуемого количества работников необходимой квалификации в национальной системе образования, но и несовершенство модели управления оплатой труда, которая не позволяет нивелировать эти дисбалансы.

В экономике растет дифференциация заработной платы по сферам и видам экономической деятельности. Если ранее по видам экономической деятельности она различалась в 2,5-2,7 раза, то за 2015-2018 гг. произошло увеличение этого разрыва до 4,2 раз. В лучшем положении по оплате труда до 2014 г. находились финансовая и стра- ховая деятельность, уступившие затем первенство информации и связи. Значительно выше среднего оплачивается профессиональная, научная и техническая деятельность, труд в сфере государственного управления (рис. 2). К аутсайдерам традиционно относятся следующие виды деятельности: услуги по временному проживанию и питанию, сельское, лесное и рыбное хозяйство, образование, здравоохранение и социальные услуги. При этом чаще всего укрупненную группировку видов деятельности замыкают услуги по временному проживанию и питанию (2011, 2012, 2015, 2017 гг.) или образование (2013, 2014, 2018 гг.).

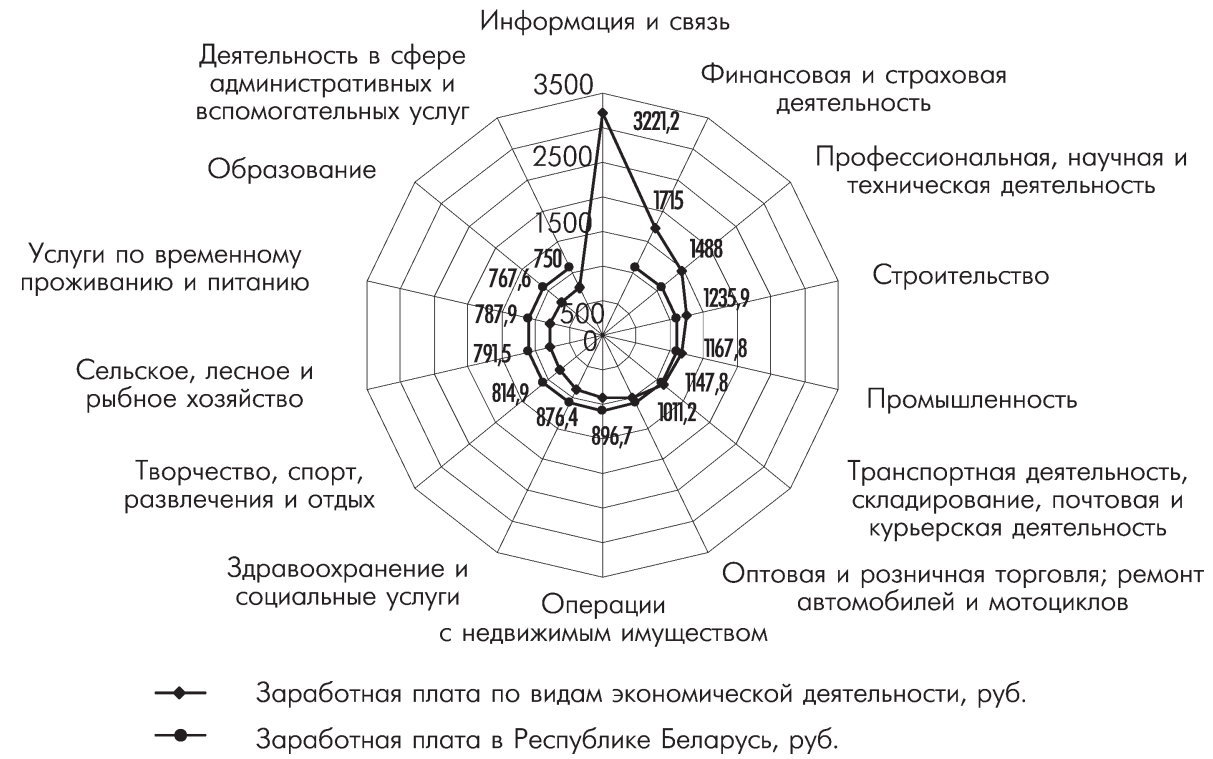

Рис. 2. Среднемесячная заработная плата по видам экономической деятельности в Республике Беларусь, 2019 г.

Источник. Авторская разработка на основе URL: https://www.belstat.gov.by/ofitsialnaya-statistika/realnysector-ekonomiki/stoimost-rabochey-sily/godovye-dannye/nominalnaya-nachislennaya-srednemesyachnaya-zarabotnayaplata-po-oblastyam-i-g-minsku/ 
Сопоставление уровня заработной платы работников с уровнем их образования, отражаемым долей работников с высшим и средним специальным образованием, в разрезе видов экономической деятельности, выполненное с применением методов непараметрического анализа взаимосвязей, показало отсутствие статистически значимой связи между этими показателями. Наибольший разрыв между уровнями этих параметров наблюдается в образовании и здравоохранении, где размер заработной платы несправедливо низок. В 2019 г. уровень заработной платы работников образования (767,6 руб.), имеющих сопоставимый с работниками государственного управления уровень образования, был ниже, чем в сельском, лесном и рыбном хозяйстве (791,5 руб.), где заняты наименее образованные работники.

Важнейшим для экономики Беларуси видом экономической деятельности является промышленность, где занято около 1 млн чел. Она представлена большим спектром производств, значительно различающихся как условиями функционирования, так и результатами деятельности, уровнем заработной платы работников. Дифференциация заработной платы в рамках промышленности менее глубока, чем ее различия по видам экономической деятельности. Лидируют здесь производства химических продуктов, кокса и нефтепродуктов, горнодобывающая промышленность, производство фармацевтических продуктов и препаратов, производство вычислительной, электронной и оптической аппаратуры, энергетика. Бессменным аутсайдером по параметру заработной платы является производство текстильных изделий, одежды, изделий из кожи и меха. Низкий уровень заработков характерен для деревообрабатывающих производств, деятельности в сфере водоснабжения, сбора, обработки и удаления отходов.

В целом, пропорции в оплате труда различного уровня сложности далеки от совершенства, при этом в неудовлетворительном положении находятся многие работники бюджетной сферы и низкорентабельных видов деятельности, готовые при случае сменить не только место работы, но и профессию, а высокая заработная плата в Беларуси имеет место в производствах и видах деятельности, связанных с функционированием естественных монополий, доступом к природным ресурсам, применением новейших технологий (информационных, финансовых, др.) и уникальных человеческих способностей. Это обусловлено слабостью реализации регулирующей функции оплаты труда и ведет к дисбалансам на рынке труда.

\section{Стимулирующая функщия оплаты труда}

Стимулирующая функция оплаты труда, обеспечивающая мотивацию работников к труду, следует за воспроизводственной, компенсирующей и регулирующей, должное выполнение которых создает необходимые предпосылки для ее реализации. Помимо слабых предпосылок выполнения стимулирующей функции следует иметь в виду несовершенство институтов и институциональных инструментов, обеспечивающих реализацию стимулирующей функции оплаты труда, на что, в частности, указывает низкая доля субъектов хозяйствования, применяющих гибкие системы оплаты труда.

О выполнении стимулирующей функции оплаты труда позволяет судить динамика производительности труда. За 2011-2018 гг. производительность труда в сопоставимых ценах выросла на 18,3\% (среднегодовой рост - 2,1\%), в долларовом выражении - с 11,8 до 13,0 тыс. долл. США, т. е. на 10,2\% (среднегодовой рост $1,2 \%$ ), а исчисленная в долларах США по ППС - с 34,7 в 2011 г. до 40,9 тыс. долл. в 2017 г., т. е. на 17,9\%, продемонстрировав 2,8\%-й среднегодовой прирост (табл. 11). В то же время по данным Всемирного банка в 2010-2017 гг. производительность в Беларуси снижалась в среднем на $2 \%$ в год 6 .

На фоне отсутствия устойчивого роста производительности труда реальная заработная плата демонстрировала более высокие темпы прироста. Если в 2018 г. производительность труда была лишь на 18,3\% выше, чем в 2010 г., то реальная заработная плата за этот период увеличилась на 65,8\%. Отсюда следует, что увеличение реальной заработной платы шло в отрыве от производительности труда и, наоборот, ее рост не сопро-

${ }^{6}$ URL: http://kef.by/forum/kef-2018/video2018/ 
Динамика производительности труда и реальной заработной платы в Республике Беларусь

\begin{tabular}{|c|c|c|c|c|c|c}
\hline \multirow{2}{*}{ Год } & \multicolumn{3}{|c|}{ Производительность труда } & \multicolumn{2}{c}{ Реальная заработная плата } \\
\cline { 2 - 7 } & $\begin{array}{c}\text { в сопоставимых } \\
\text { црнд, \% к уровню }\end{array}$ & $\begin{array}{c}\text { в сопоставимых } \\
\text { ценах, \% к } \\
\text { провню 2010 г. }\end{array}$ & $\begin{array}{c}\text { тыс. долл. } \\
\text { США }\end{array}$ & $\begin{array}{c}\text { тыс. долл. } \\
\text { США по ППС }\end{array}$ & $\begin{array}{c}\text { в сопоставимых } \\
\text { ценах, \% к уровню } \\
\text { предыдущего года }\end{array}$ & $\begin{array}{c}\text { уровню } \\
2010 \text { г. }\end{array}$ \\
\hline 2010 & 107,2 & 100,0 & 11,8 & - & 115,0 & 100,0 \\
\hline 2011 & 105,7 & 105,7 & 13,7 & 34,7 & 101,9 & 101,9 \\
\hline 2012 & 103,5 & 109,4 & 13,8 & 36,4 & 121,5 & 123,8 \\
\hline 2013 & 101,7 & 111,3 & 16,0 & 37,6 & 116,4 & 144,0 \\
\hline 2014 & 102,3 & 113,8 & 16,7 & 39,1 & 101,3 & 145,8 \\
\hline 2015 & 97,4 & 110,9 & 12,2 & 38,5 & 97,7 & 142,5 \\
\hline 2016 & 99,5 & 110,3 & 10,8 & 38,8 & 96,2 & 137,2 \\
\hline 2017 & 103,7 & 114,3 & 12,5 & 40,9 & 107,5 & 147,3 \\
\hline 2018 & 103,4 & 118,3 & 13,0 & - & 112,6 & 165,8 \\
\hline
\end{tabular}

Источник. Авторская разработка на основе: Статистический ежегодник Республики Беларусь, 2019: стат. сборник. 2019. Минск: Национальный статистический комитет Республики Беларусь. С. 25, 26; Национальные счета Республики Беларусь, 2019: стат. сборник. 2019. Минск: Национальный статистический комитет Республики Беларусь. С. 23, 24.

вождался эквивалентным ростом производительности труда, что вызывает сомнения в объективности предпосылок для подобной динамики заработной платы и указывает на неэффективность применяемых систем оплаты труда, не обеспечивающих увязку параметров производительности труда и заработной платы и не способных поддерживать устойчивую мотивацию к труду.

Социологические исследования показывают, что у работников доминируют материалистические потребности, а ценности самореализации, личной ответственности и инициативы находятся на периферии сознания. Работники преследуют две стратегии в сфере труда: традиционную, характерную для старшего поколения, выражающуюся в стремлении обеспечить приемлемый, принятый в обществе стандарт жизни, и свойственную для молодого поколения стратегию максимизации труда, соответствующую рыночным условиям и выражающуюся в том, чтобы работать более интенсивно для обеспечения как можно более высокого стандарта жизни. При этом у работников присутствует убежденность в том, что добросовестный труд и богатство не связаны между собой, а благосостояние часто определяется личными связями и волею случая (Таранова, 2015).

\section{Социальная функция оплаты труда}

Рассмотрение индикаторов реализации воспроизводственной, компенсирующей, регулирующей и стимулирующей функций показало отсутствие значимых предпосылок для выполнения в полном объеме социальной функции оплаты труда.

Статистика свидетельствует о неуклонном росте номинальной заработной платы наемных работников в Республике Беларусь. В 2019 г. по сравнению с дореформенным 1990 г. уровень номинальной заработной платы (1091 руб.) возрос более чем в 40 тысяч раз, по сравнению с 2000 г. более чем в 180 раз, а в сопоставлении с 2010 г. - почти в 9 раз (рис. 3). В условиях высокой инфляции показатели среднемесячной заработной платы малоинформативны, однако сами по себе чрезвычайно высокие темпы ее роста указывают на хронические проблемы экономики, и в сфере оплаты труда в том числе.

Небольшая дифференциация доходов населения во многом определяется относительно невысокими различиями в заработной плате. Так, в 2018 г. доходы наиболее и наименее обеспеченных 10\% групп населения различались в 6,0 раз (с учетом трансфертов, предпринимательских доходов и доходов от собственности). При этом каждый четвертый работник получал низкую заработную плату (ниже 2/3 медианного значения). Однако такая оценка дифференциации заработной платы слишком укрупнена. Целесообразным является рассмотрение различий в заработной плате не только в межотраслевом и профессионально-квалификационном, но также в региональном и гендерном аспектах. 


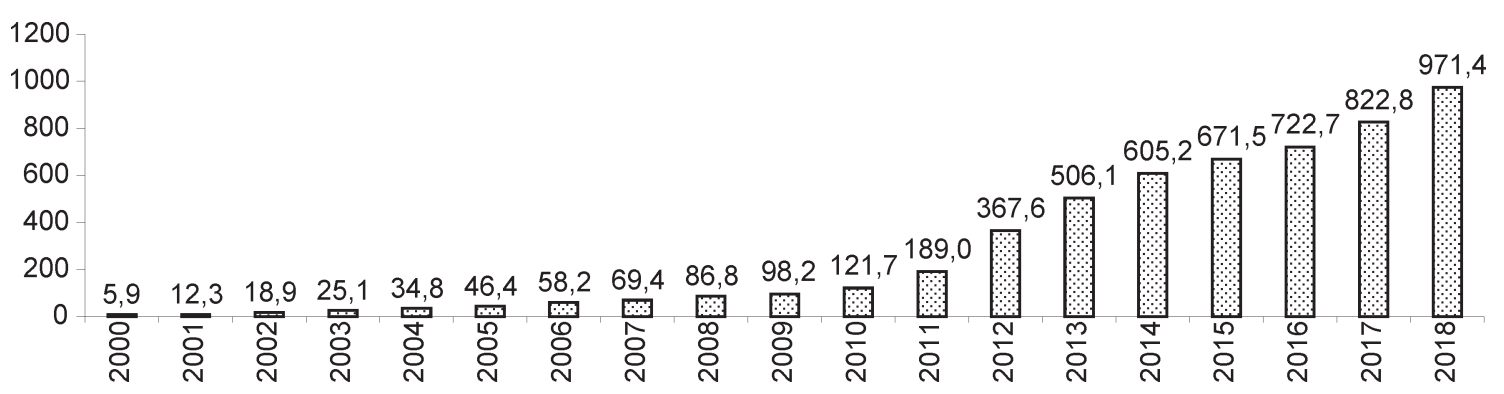

Примечание. Данные приведены в действующем масштабе цен.

Рис. 3. Динамика номинальной начисленной среднемесячной заработной платы работников в Республике Беларусь (с микро- и малыми организациями)

Источник. Авторская разработка на основе: URL: https://www.belstat.gov.by/ofitsialnaya-statistika/realnysector-ekonomiki/stoimost-rabochey-sily/operativnye-dannye/nominalnaya-nachislennaya-srednyaya-zarabotnaya-platarabotnikov-respubliki-belarus-s-1991-po-2018-g/

Заметных диспропорций в оплате труда между регионами (областями) не наблюдается. Самой высокой заработной платой и наиболее быстрым ее ростом характеризуется г. Минск, который, обладая статусом столицы страны, концентрирует значительную часть ее материальных, финансовых и трудовых ресурсов. Самая низкая заработная плата до 2015 г. была традиционна для Брестской области, считающейся сельскохозяйственным регионом страны, однако в последние годы на последнюю позицию опустилась Могилевская область. Коэффициент межрегиональной дифференциации заработной платы, ранее отличавшийся стабильностью, в последние годы демонстри- рует рост с 1,44 в 2013 г. до 1,70 в 2019 г. Исключение из расчетов Минска сужает пределы дифференциации заработной платы по регионам страны до 1,09-1,22 (табл. 12).

Заработная плата по областям примерно на $12-18 \%$ ниже, чем в среднем по республике. Рассмотрение же ее дифференциации в рамках отдельных областей позволяет получить ряд следующих выводов. Заработная плата в населенных пунктах Минской области различается более чем в 2,1 раза. Связано это с тем, что в Солигорском районе функционирует флагман мировой калийной промышленности ОАО «Беларуськалий». Средняя заработная плата работников в Солигорском рай-

Среднемесячная заработная плата по регионам Республики Беларусь, руб.

Таблица 12

\begin{tabular}{|c|c|c|c|c|c|c|c|c|c|}
\hline \multirow[b]{2}{*}{ Год } & \multirow[b]{2}{*}{ 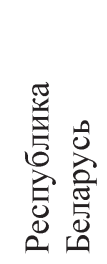 } & \multirow[b]{2}{*}{$\sum_{\dot{L}}^{\frac{y}{0}}$} & \multicolumn{6}{|c|}{ Область } & \multirow[b]{2}{*}{$\begin{array}{c}\text { Коэффициент } \\
\text { дифференциации } \\
\text { заработной } \\
\text { платы }\end{array}$} \\
\hline & & & 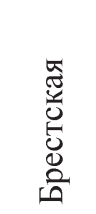 & 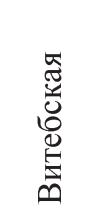 & 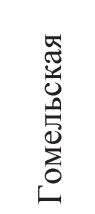 & 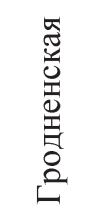 & 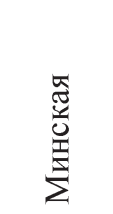 & 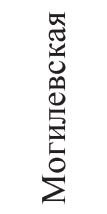 & \\
\hline 2010 & 121,7 & 153,7 & 108,8 & 109,0 & 115,2 & 110,5 & 118,2 & 109,0 & 1,41 \\
\hline 2011 & 190,0 & 240,4 & 164,7 & 170,9 & 179,0 & 171,5 & 187,8 & 171,3 & 1,46 \\
\hline 2012 & 367,6 & 457,5 & 318,5 & 331,3 & 351,7 & 329,7 & 366,0 & 336,5 & 1,44 \\
\hline 2013 & 506,1 & 636,8 & 443,1 & 450,7 & 481,6 & 457,9 & 496,2 & 453,6 & 1,44 \\
\hline 2014 & 605,2 & 773,1 & 529,4 & 533,8 & 564,2 & 542,7 & 598,7 & 531,1 & 1,46 \\
\hline 2015 & 671,5 & 887,3 & 575,7 & 580,5 & 609,6 & 592,0 & 666,8 & 579,1 & 1,54 \\
\hline 2016 & 722,7 & 985,8 & 617,4 & 613,4 & 633,5 & 622,4 & 713,3 & 609,3 & 1,62 \\
\hline 2017 & 822,8 & 1125,5 & 699,1 & 687,3 & 722,9 & 703,2 & 812,9 & 690,4 & 1,63 \\
\hline 2018 & 971,4 & 1329,8 & 828,4 & 814,4 & 853,3 & 831,9 & 958,6 & 802,0 & 1,66 \\
\hline 2019 & 1090,9 & 1524,3 & 942,6 & 918,9 & 974,5 & 939,8 & 1098,3 & 898,5 & 1,70 \\
\hline
\end{tabular}

Источник. Авторская разработка на основе: URL: https://www.belstat.gov.by/ofitsialnaya-statistika/solialnayasfera/trud/godovye-dannye/nom_sredn_zarab_plata_91-2013/ 
оне в 2019 г. (1650,8 руб.) превышала столичную заработную плату (1524,3 руб.) более чем на $8 \%$. Значительные различия в уровне заработной платы характерны для Витебской области, где в г. Новополоцк расположен белорусский нефтеперерабатывающий гигант OAO «Нафтан». Средняя заработная плата по г. Новополоцку в 2019 г. составляла 1235,5 руб., что на 13\% было выше средней по стране. Высокая заработная плата характерна для г. Жодино, Минского, Дзержинского, Речицкого, Мозырского, Смолевичского, Жлобинского, Светлогорского районов страны, где располагаются крупные промышленные предприятия (Белорусский автомобильный завод, Белорусский металлургический завод, Мозырский нефтеперерабатывающий завод и др.), и, в некоторой степени, для областных городов. Сопоставление же административных районов в масштабах страны показывает значительные различия в оплате труда, к примеру, у работников самого «богатого» Солигорского района и самого «бедного» Шарковщинского района страны (фонд заработной платы на $70 \%$ формируется из заработков работников сельского хозяйства и бюджетной сферы) заработная плата отличается почти в 2,5 раза.

Очевидно, что межрегиональная дифференциация заработной платы в значительной степени определяется отраслевой структурой производства в регионах и связана с функционированием крупных промышленных предприятий и, прежде всего, предприятий-монополистов, генерирующих высокую добавленную стоимость в расчете на одного работника. Между тем основными целями социально-экономического развития регионов Республики Беларусь остается повышение уровня благосостояния населения независимо от мест его проживания и уменьшение существующих различий между регионами на основе наиболее эффективного использования их преимуществ.

В вопросах оплаты труда необходимо учитывать не только профессионально-квалификационные, но и гендерные характеристики работников. Особенностью трудовых ресурсов Беларуси является то, что в трудоспособном возрасте женщины по численности не уступают мужчинам, а по своим качественным характеристикам - имеют преимущества перед ними. Женщины составляют более половины населения Беларуси (53,4\% в 2018 г.), их доля в составе занятого населения близка к 50\%. Белорусские женщины более образованны, чем мужчины: каждая третья из числа занятых в экономике имеет высшее образование, каждая четвертая - среднее специальное. В 2018 г. почти 64\% работающих женщин имели высшее и среднее специальное образование, тогда как среди мужчин таковых было лишь 46\% (табл. 13).

В обществе сформировалось разделение сфер деятельности на преимущественно мужские (лесное и рыбное хозяйство, промышленность, транспорт, строительство, ремонт и эксплуатация) и женские (здравоохранение и предоставление социальных услуг, образование, финансирование и страхование, гостиницы и рестораны, торговля и бытовые услуги). Соотношение средней заработной платы женщин и мужчин (параметр Системы индикаторов достойного труда) в декабре 2018 г. составило 72,7\%. Анализ показывает преимущество мужчин во всех видах экономической деятельнос-

Таблица 13

Распределение мужчин и женщин по уровню образования в Республике Беларусь, \% от общей численности их контингента в организациях

\begin{tabular}{|c|c|c|c|c|}
\hline \multirow[b]{2}{*}{ Год } & \multicolumn{2}{|c|}{ Мужчины } & \multicolumn{2}{|c|}{ Женщины } \\
\hline & $\begin{array}{c}\text { с высшим } \\
\text { образованием }\end{array}$ & $\begin{array}{c}\text { со средним специальным } \\
\text { образованием }\end{array}$ & $\begin{array}{c}\text { с высшим } \\
\text { образованием }\end{array}$ & $\begin{array}{c}\text { со средним специальным } \\
\text { образованием }\end{array}$ \\
\hline 2012 & 23,0 & 17,2 & 31,1 & 26,8 \\
\hline 2014 & 24,6 & 17,6 & 33,3 & 26,5 \\
\hline 2016 & 26,8 & 18,0 & 36,2 & 26,1 \\
\hline 2017 & 27,7 & 17,9 & 36,7 & 27,8 \\
\hline 2018 & 28,2 & 17,8 & 38,1 & 25,7 \\
\hline
\end{tabular}

Источник. Авторская разработка на основе: Труд и занятость в Республике Беларусь, 2018: стат. сборник. 2018. Минск: Национальный статистический комитет Республики Беларусь. С. 119-120; Статистический ежегодник Республики Беларусь, 2019: стат. сборник. 2019. Минск: Национальный статистический комитет Республики Беларусь. С. 77. 
ти, в том числе, в здравоохранении и образовании (табл. 14). При этом активисты женского движения отмечают, что заработки в низкооплачиваемых сферах вынуждают женщин работать на полторы (две) ставки, что не находит отражения в официальной статистике и маскирует дискриминацию на рынке труда.

Анализ распределения мужчин и женщин по категориям персонала в 2018 г. показывает, что руководителей среди мужчин больше, чем среди женщин - 12,2 и 9,8\% соответственно. В то же время большинство мужчин работает на рабочих должностях $(68,0 \%)$, тогда как женщин на таких должностях занято меньше половины (42,9\%). Так, доля женщин, занятых на должностях специалистов, составляет $42,2 \%$ и значительно превосходит долю мужчин на этих должностях - 18,3\%. В целом доля руководителей и специалистов среди женщин $(51,5 \%)$ в 1,7 раза выше, чем среди мужчин $(30,2 \%)^{7}$.

${ }^{7}$ Статистический ежегодник Республики Беларусь, 2019: стат. сборник. 2019. Минск: Национальный статистический комитет Республики Беларусь. С. 81.
Статистика показывает, что заработная плата женщин ниже не только среди руководителей, но и практически по всем группам занятий, а если смотреть дифференцированно - то особенно у специалистов-профессионалов, специалистов и неквалифицированных работников (на 30-40\%). Таким образом, несмотря на то, что женщины более образованы и чаще мужчин занимают должности руководителей и специалистов, по уровню заработной платы они им значительно уступают, что во многом обусловлено низким уровнем государственных гарантий по оплате труда.

В целом невысокий средний уровень заработной платы и ее необоснованная дифференциация в межотраслевом, профессионально-должностном, региональном и гендерном разрезах, а также наличие случаев несвоевременной выплаты заработной платы, создают предпосылки для дестабилизации трудовых коллективов (по данным Института социологии НАН Беларуси в декабре 2018 г. только каждый четвертый работник был удовлетворен отношениями в трудовом коллективе и лишь каждый пятый своей ра-

Таблица 14

Заработная плата мужчин и женщин по видам экономической деятельности в Республике Беларусь в декабре 2018 г.

\begin{tabular}{|l|c|}
\hline \multicolumn{1}{|c|}{ Вид экономической деятельности } & $\begin{array}{c}\text { Соотношение заработной } \\
\text { платы женщин и мужчин, \% }\end{array}$ \\
\hline Вся экономика & 72,7 \\
\hline Сельское, лесное и рыбное хозяйство & 70,7 \\
\hline Промышленность & 73,9 \\
\hline Строительство & 83,0 \\
\hline Оптовая и розничная торговля; ремонт автомобилей и мотоциклов & 72,4 \\
\hline $\begin{array}{l}\text { Транспортная деятельность, складирование, почтовая и курьерская } \\
\text { деятельность }\end{array}$ & 94,4 \\
\hline Услуги по временному проживанию и питанию & 81,8 \\
\hline Информация и связь & 55,9 \\
\hline Финансовая и страховая деятельность & 73,6 \\
\hline Операции с недвижимым имуществом & 88,0 \\
\hline Профессиональная, научная и техническая деятельность & 76,9 \\
\hline Деятельность в сфере административных и вспомогательных услуг & 81,0 \\
\hline Государственное управление & 87,9 \\
\hline Образование & 86,1 \\
\hline Здравоохранение и социальные услуги & 82,6 \\
\hline Творчество, спорт, ра звлечения и отдых & 59,3 \\
\hline Предоставление прочих видов услуг & 66,1 \\
\hline
\end{tabular}

Источник. Авторская разработка на основе: Численность, заработная плата работников, затраты организаций Республики Беларусь на рабочую силу в 2018 году: стат. бюллетень. 2019. Минск: Национальный статистический комитет Республики Беларусь. С. 27. 
ботой в целом) и формирования социальной напряженности. В табл. 15 представлена динамика уровня социальной напряженности в стране, рассчитанного А. М. Бельским (2018) по методике, разработанной Центром социологических и политических исследований Белорусского государственного университета, на фоне динамики показателей покупательной способности заработной платы. Из таблицы следует, что траектория показателя социальной напряженности в значительной мере корреспондирует с динамикой покупательной способности заработной платы (наблюдается рост социальной напряженности по мере, а уровень социальной напряженности приближается к критической черте (25\%) (Бельский, 2018), что не способствует росту конкурентоспособности национальной экономики.

Прямые и косвенные индикаторы реализации воспроизводственной, компенсирующей, регулирующей, стимулирующей и социальной функций свидетельствуют о слабости предпосылок для эффективного выполнения функции поддержания конкурентоспособности хозяйственной системы.

\section{Функция поддержания конкурентоспособности хозяйственной системы}

Функция поддержания конкурентоспособности экономического субъекта связана с оптимизацией (минимизацией) затрат на оплату труда с тем, чтобы, с одной стороны, обеспечить формирование издержек на производство продукции на уровне, позволяющем сохранять конкурентоспособ- ность продукции, с другой, - возможность выплаты конкурентной заработной платы, достаточной для привлечения и удержания квалифицированных кадров, что в целом оборачивается созданием условий для роста производительности труда.

Статистика показывает небольшой, но стабильный рост фондовооруженности труда, который не сопровождается эквивалентным ростом производительности труда (табл. 16), что может быть следствием как недостаточности темпов обновления основных средств, так и отсутствия мотивации к труду.

Степень обновления основных средств зависит от пропорций в распределении первичных доходов. С 2000 г. доля оплаты труда в ВВП увеличилась, что сопровождалось сокращением доли валовой прибыли и предпосылок для расширения материальной и технологической базы производства (рис. 4). На этом фоне шло постепенное снижение инвестиционной привлекательности белорусской экономики и сжатие инвестиционных возможностей предприятий в условиях дефицита финансовых ресурсов в стране.

Доля оплаты труда в ВВП в Беларуси стремится к 50\% - уровню, характерному для самых развитых стран мира. В 20172018 гг. она составляла около 47\% при доле валовой прибыли и валовых смешанных доходов 38\%. Что касается сопредельных стран, то в 2016 г. в России, Латвии и Литве она достигла 48, 46 и 44\% соответственно, а в Польше и Украине - 38 и $37 \%$. Доля валовой прибыли и валовых смешанных доходов в ВВП в первой группе стран со-

Таблица 15

Динамика показателей социальной напряженности и покупательной способности заработной платы в Республике Беларусь

\begin{tabular}{|l|c|c|c|c|c|c|c|c|}
\hline \multicolumn{1}{|c|}{ Показатель } & 2010 & 2011 & 2012 & 2013 & 2014 & 2015 & 2016 & 2017 \\
\hline Уровень социальной напряженности, \% & 28,8 & 17,8 & 9,6 & 9,6 & 9,6 & 18,6 & 21,1 & 23,8 \\
\hline $\begin{array}{l}\text { Индекс реальной заработной платы, \% к уровню } \\
\text { предыдушего года }\end{array}$ & 115,0 & 101,9 & 121,5 & 116,4 & 101,3 & 97,7 & 96,2 & 107,5 \\
\hline $\begin{array}{l}\text { Соотношение среднемесячной заработной платы с } \\
\text { минимальным потребительским бюджетом на } \\
\text { одного члена семьи из четырех человек, \% }\end{array}$ & 272,8 & 259,0 & 282,7 & 314,7 & 300,0 & 277,8 & 254,3 & 259,0 \\
\hline Среднемесячная заработная плата, долл. США & 406,6 & 338,9 & 439,2 & 564,2 & 589,9 & 413,1 & 361,4 & 425,6 \\
\hline
\end{tabular}

Источник. Авторская разработка на основе: (Бельский, 2018. С. 120); Труд и занятость в Республике Беларусь, 2018: стат. сборник. 2018. Минск: Национальный статистический комитет Республики Беларусь. С. 21; Беларусь и страны мира, 2018: стат. сборник. 2018. Минск: Национальный статистический комитет Республики Беларусь. С. 78. 
Индексы производительности труда и фондовооруженности труда в Республике Беларусь, в сопоставимых ценах, \%

\begin{tabular}{|c|c|c|c|c}
\hline \multirow{2}{*}{ Год } & \multicolumn{2}{|c|}{ Индекс производительности труда по ВВП } & \multicolumn{2}{c}{ Индекс фондовооруженности труда } \\
\cline { 2 - 5 } & к уровню предыдущего года & к уровню 2010 г. & к уровню предыдущего года & к уровню 2010 г. \\
\hline 2010 & 107,2 & 100,0 & 101,9 & 100,0 \\
\hline 2011 & 105,7 & 105,7 & 102,8 & 102,8 \\
\hline 2012 & 103,5 & 109,4 & 103,8 & 106,7 \\
\hline 2013 & 101,7 & 111,3 & 103,6 & 110,5 \\
\hline 2014 & 102,3 & 113,4 & 103,5 & 11,4 \\
\hline 2015 & 97,4 & 110,9 & 103,6 & 123,5 \\
\hline 2016 & 99,5 & 110,3 & 104,5 & 128,7 \\
\hline 2017 & 103,6 & 114,3 & 103,9 & 132,9 \\
\hline 2018 & 103,4 & 118,3 & 103,2 & \\
\hline
\end{tabular}

Источник. Авторская разработка на основе: Статистический ежегодник Республики Беларусь, 2019: стат. сборник. 2019. Минск: Национальный статистический комитет Республики Беларусь. С. 24.

ставляла $42-46 \%$, во второй группе - 48$50 \%$.

Таким образом, на фоне соседних стран Беларусь отличается относительно высокой долей оплаты труда в ВВП и сравнительно низкой долей валовой прибыли и валовых смешанных доходов в ВВП. Изменение пропорций в распределении первичных доходов напрямую связано с соотношением темпов роста производительности труда и заработной платы (табл. 17). Очевидно, что в ряде периодов заработная плата работников росла быстрее их выработки.

Сопоставление темпов роста номинальных (исчисленных в текущих ценах) показателей ВВП на 1 занятого и заработной платы, позволяет сравнивать интен-

${ }^{8}$ Беларусь и страны мира, 2018: стат. сборник. 2018. Минск: Национальный статистический комитет Республики Беларусь. С. $184-185$. сивность денежных потоков, связанных с производством и распределением общественного продукта. Обязательным при выполнении анализа считается сравнение темпов роста производительности труда по ВВП в сопоставимых ценах и темпов роста реальной заработной платы, позволяющее соотнести изменение интенсивности уже не денежных, а материальных, или «физических», потоков общественного продукта с одной стороны, и совокупности благ и услуг, приобретаемых на заработную плату, с другой.

Динамика коэффициентов опережения и коэффициентов эластичности, характеризующих соотношение темпов роста (прироста) производительности труда и реальной заработной платы, свидетельствует о том, что из года в год прирост производительности труда уступал приросту заработ-

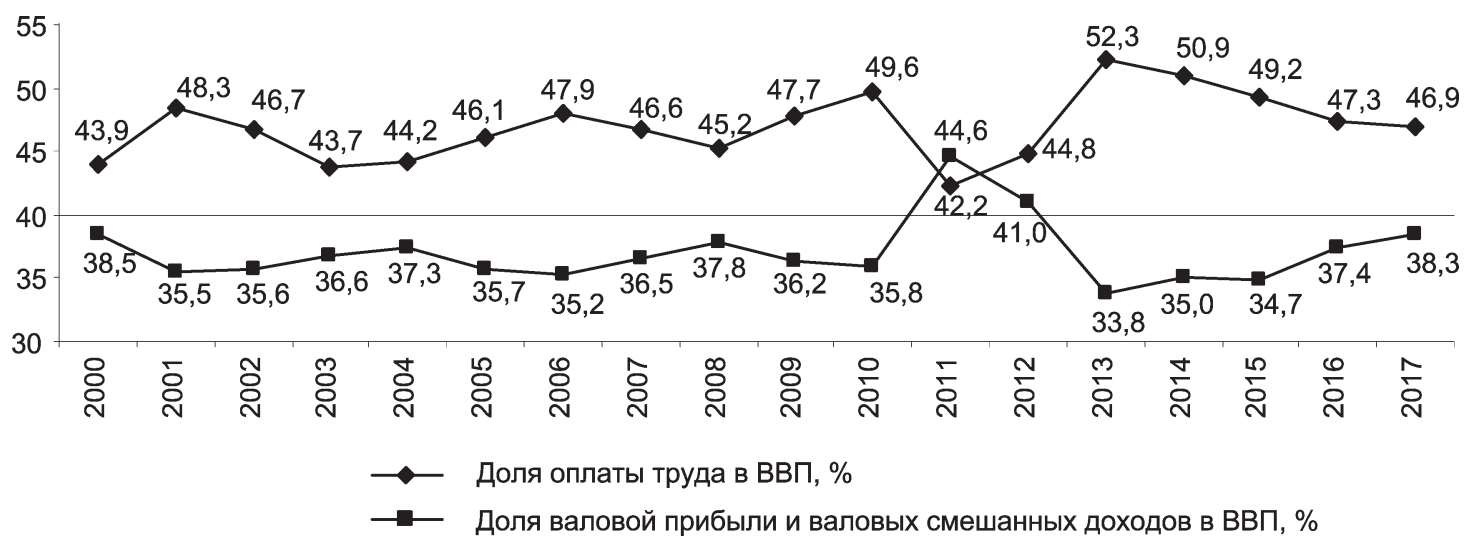

Рис. 4. Динамика доли оплаты труда в ВВП в Республике Беларусь

Источник. Авторская разработка на основе: Статистический ежегодник Республики Беларусь, 2019: стат. сборник. 2019. Минск: Национальный статистический комитет Республики Беларусь. С. 192. 
Динамика ВВП на одного занятого и заработной платы в Республике Беларусь

\begin{tabular}{|c|c|c|c|}
\hline Период & $\begin{array}{c}\text { Индекс ВВП на 1 занятого в } \\
\text { текущих ценах }\end{array}$ & $\begin{array}{c}\text { Индекс начисленной } \\
\text { заработной платы }\end{array}$ & $\begin{array}{c}\text { Коэффициент опережения, } \\
\text { раз (гр.2/гр.3) }\end{array}$ \\
\hline $1991-1995$ & 32977 & 28072 & 1,175 \\
\hline $1996-2000$ & 74,66 & 78,02 & 0,957 \\
\hline $2001-2005$ & 7,172 & 7,873 & 0,911 \\
\hline $2006-2010$ & 2,459 & 2,625 & 0,937 \\
\hline $2011-2015$ & 5,518 & 5,517 & 1,000 \\
\hline 2016 & 1,078 & 1,076 & 1,002 \\
\hline 2017 & 1,121 & 1,138 & 0,985 \\
\hline 2018 & 1,154 & 1,181 & 0,977 \\
\hline
\end{tabular}

Источник. Авторская разработка на основе: Статистический ежегодник Республики Беларусь, 2019: стат. сборник. 2019. Минск: Национальный статистический комитет Республики Беларусь. С. 18-21.

ной платы (табл. 18). Рост покупательной способности населения опережал рост товарной массы в национальной экономике, увеличение заработной платы не стимулировало работников к адекватному повышению производительности труда. Это приводило к перегреву внутренней экономики, усиливая инфляцию, ограничивая конкурентоспособность, обостряя дисбалансы, подавляя стремление населения к накоплению сбережений. Не менее важно и то, что повышение заработной платы, не подкрепляемое ростом производительности, подрывает стимулы к труду.

Современная Беларусь относится к числу стран с низким уровнем производительности труда и заработной платы, уступая по этому параметру странам Западной и Северной Европы, постсоциалистическим странам Центральной и Восточной Европы, Российской Федерации, Казахстану. Особый интерес представляет сопоставление уровня заработной платы в Республи- ке Беларусь с его уровнем в сопредельных государствах, находящихся по «периметру» страны (табл. 19). Эти страны имеют общее с Беларусью прошлое, поддерживают хозяйственные и культурные связи и представляют собой ближайшие национальные рынки труда.

В этом рейтинге по уровню заработной платы, исчисленной в долларовом эквиваленте, страна опережает лишь Украину. Относительный разрыв с Польшей, лидирующей в этой группе стран, сохранился - заработная плата выше в 2,8 раза, тогда как абсолютный - возрос с 717 долл. США в 2010 г. до 842 в 2018 г. Потому рынки большинства сопредельных стран с учетом их непосредственной близости привлекательны для белорусских граждан. Отставание от сопредельных государств формирует потенциал миграции. По статистическим данным, количество граждан Беларуси, выехавших за пределы страны, увеличилось с 7,6 тыс. чел. в 2011 г. до 15,2 тыс. в 2018 г. (табл. 20). Большинство

Таблица 18

Динамика производительности труда и реальной заработной платы в Республике Беларусь

\begin{tabular}{|c|c|c|c|c|}
\hline Период & $\begin{array}{c}\text { Ироизводительности труда } \\
\text { по ВВП, \% }\end{array}$ & $\begin{array}{c}\text { Индекс реальной } \\
\text { заработной платы, \% }\end{array}$ & $\begin{array}{c}\text { Коэффициент } \\
\text { опережения, гр.2/гр.3 }\end{array}$ & $\begin{array}{c}\text { Коэффициент } \\
\text { эластичности, \% }\end{array}$ \\
\hline 1 & 2 & 3 & 4 & 5 \\
\hline $1991-1995$ & 76,2 & 55,7 & 1,368 & 1,861 \\
\hline $1996-2000$ & 134,7 & 170,4 & 0,792 & 2,029 \\
\hline $2001-2005$ & 144,4 & 204,8 & 0,705 & 2,360 \\
\hline $2006-2010$ & 134,3 & 161,8 & 0,830 & 1,802 \\
\hline $2011-2015$ & 110,9 & 142,6 & 0,778 & 3,908 \\
\hline 2016 & 99,5 & 96,2 & 1,034 & - \\
\hline 2017 & 103,6 & 107,5 & 0,964 & 2,083 \\
\hline 2018 & 103,4 & 112,6 & 0,915 & 3,706 \\
\hline
\end{tabular}

Источник. Авторская разработка на основе: Статистический ежегодник Республики Беларусь, 2019: стат. сборник. 2019. Минск: Национальный статистический комитет Республики Беларусь. С. 25-26. 
Среднемесячная заработная плата работников в Республике Беларусь и сопредельных странах, долл. США

\begin{tabular}{|c|c|c|c|c|c|c|c|}
\hline \multirow{2}{*}{ Год } & \multicolumn{3}{|c|}{ Страны СНГ } & \multicolumn{3}{|c|}{ Страны Европейского союза } & \multirow{2}{*}{$\begin{array}{l}\text { Польша/ } \\
\text { Беларусь }\end{array}$} \\
\hline & Украина & Беларусь & Россия & Латвия & Литва & Польша & \\
\hline 2010 & 282,2 & 406,6 & 681,6 & 839,2 & 763,3 & 1124,0 & 2,76 \\
\hline 2011 & 330,5 & 338,9 & 796,2 & 918,7 & 826,7 & 1200,6 & 3,54 \\
\hline 2012 & 378,7 & 439,2 & 857,1 & 880,1 & 785,3 & 1117,4 & 2,54 \\
\hline 2013 & 408,5 & 564,2 & 936,3 & 950,9 & 855,8 & 1169,4 & 2,07 \\
\hline 2014 & 293,3 & 589,9 & 855,8 & 1016,3 & 897,7 & 1195,9 & 2,03 \\
\hline 2015 & 192,5 & 413,1 & 561,0 & 907,6 & 791,6 & 1009,1 & 2,44 \\
\hline 2016 & 202,8 & 361,4 & 548,7 & 950,8 & 856,3 & 1008,1 & 2,79 \\
\hline 2017 & 272,8 & 425,6 & 671,1 & 1046,1 & 948,3 & 1122,5 & 2,64 \\
\hline Октябрь 2018 & 327 & 471 & 634 & 1150 & 1035 & 1313 & 2,79 \\
\hline
\end{tabular}

Источник. Авторская разработка на основе: Беларусь и страны мира, 2018: стат. сборник. 2018. Минск: Национальный статистический комитет Республики Беларусь. С. 78, 79; Как отличаются зарплаты в Беларуси и соседних странах. URL: https://ej.by/news/economy/2018/12/01/kak-otlichayutsya-zarplaty-v-belarusi-i-sosednih-stranah.html

переселенцев направляется в Россию (около 70\%). При этом Беларусь теряет квалифицированную рабочую силу, которая и формирует список «дефицитных» профессий на отечественном рынке труда. По экспертным оценкам, в Российской Федерации работает до 500 тысяч белорусов. По данным Института социологии НАН Беларуси, по состоянию на июнь 2018 г. каждый пятый работник желал уехать из страны на постоянное место жительства или с целью временной работы при том, что только каждого четвертого работника можно было отнести к относительно конкурентоспособным на отечественном рынке труда.

Таким образом, статистические и социологические индикаторы указывают на низкую социально-экономическую эффективность отечественной модели оплаты труда, отражаемую в конечном итоге невысоким уровнем заработной платы. Эта модель порождает диспропорции в оплате труда работников различных профессионально-квалификационных групп, обусловленные тем, что размер заработной платы в стране в большей степени определяется условиями функционирования отраслей экономики и субъектов хозяйствования, чем сложностью трудовых функций, квалификацией работников и результатами их труда. Оплата труда работников одной и той же профессии и квалификации может в разы различаться в зависимости от того, в каком сегменте белорусской экономики они оказались. Такое расслоение затрудняет формирование гармоничного народнохозяйственного комплекса и консолидацию общества, «обескровливает» многие виды деятельности, работающие на внутренние интересы страны. Перед национальной экономикой стоит задача приведения пропорций вознаграждения работников различных по квалификации и общественной значимости профессий в соответствии с пропорциями, выработанными в наиболее успешных странах. Реформирование национальной модели оплаты труда предполагает предварительную разработку соответствующей концепции, которая должны учитывать полученные автором выводы в отношении эффективности реализации функций оплаты труда.

Таблица 20

Численность населения, эмигрировавшего из Республики Беларусь, чел.

\begin{tabular}{|c|c|c|c|c|c|c|c|c|}
\hline Миграция & 2011 г. & 2012 г. & 2013 г. & 2014 г. & 2015 г. & 2016 г. & 2017 г. & 2018 г. \\
\hline Международная миграция & 7610 & 8712 & 7792 & 9219 & 9855 & 13098 & 15087 & 15239 \\
\hline со странами СНГ & 5799 & 6509 & 5374 & 5912 & 6679 & 8997 & 9558 & 9829 \\
\hline со странами вне СНГ & 1811 & 2203 & 2418 & 3307 & 3176 & 4101 & 5529 & 5410 \\
\hline
\end{tabular}

Источник. Авторская разработка на основе: Статистический ежегодник Республики Беларусь, 2019: стат. сборник. 2019. Минск: Национальный статистический комитет Республики Беларусь. С. 68. 


\section{СПИСОК ЛИТЕРАТУРЫ (REFERENCES)}

Бельский А.М. 2018. Ключевые вызовы развития независимой Беларуси в фокусе медиа и уровень социальной напряженности: социологическая реконструкция. Журнал Белорусского государственного университета. Социология. № 4. C. 117-125. [Belski A.M. 2018. Key challenges for the development of independent Belarus in the focus of the media and the level of social tension: sociological reconstruction. Zhurnal Belorusskogo gosudarstvennogo universiteta. Sotsiologiya. No 4. PP. 117-125. (In Russ.)]

Дайнеко A.E. 2015. Сущность белорусской экономической модели и оценка эффективности ее реализации. Социально-экономическая модель: становление и развитие: теория, методология, практика. Минск: Беларуская навука. С. 236-273. [Dayneko A.E. 2015. The essence of the Belarusian economic model and assessment of the effectiveness of its implementation. Sotsial'no-ekonomicheskaya model': stanovlenie i razvitie: teoriya, metodologiya, praktika. Minsk: Belaruskaya navuka. PP. 236-273. (In Russ.)]

Кляузе В.П., Сечко Л.К. 2015 Концептуальные подходы к совершенствованию государственного управления охраной труда в 2016-2020 гг. Белорусский экономический журнал. № 1. С. 8696. [Kliauze V., Sechko L. 2015. Conceptual approaches to improvement of state labor safety regulation in 2016-2020. Belorusskiy ekonomicheskiy zhurnal. No 1. PP. 86-96. (In Russ.)]

Крупейченко О.Е. 2016. Особенности формирования демографической политики в Республике Беларусь в контексте воспроизводства населения страны и сбалансированности возрастной структуры. Новая экономика. № 1. С. 179186. [Krupeychenko O.E. 2016. Features of the formation of a demographic policy in the Republic of Belarus in the context of reproduction of the country's population and balanced age structure. Novaya ekonomika. No 1. PP. 179-186. (In Russ.)]

Соколова Г.Н. 2015. Ценности в сфере труда и трудовая мотивация населения Республики Беларусь. Традищионные ценности общества - основа сохранения межнационального согласия и толерантности: материалы Международной научно-практической конференции. Минск. С. 49-54. [Sokolova G.N. 2015. Values in the world of work and labor motivation of the population of the Republic of Belarus. Traditsionnye tsennosti obshchestva - osnova sokhraneniya mezhnatsional'nogo soglasiya i tolerantnosti: materialy Mezhdunarodnoy nauchno-prakticheskoy konferentsii. Minsk. PP. 49-54. (In Russ.)]

Таранова Е.В. 2015. Факторы трудовой мотивации белорусов. Социологический альманах. № 6. C. 436-444. [Taranova E.V. 2015. Factors of labor motivation of Belarusians. Sotsiologicheskiy al'manakh. No 6. PP. 436-444. (In Russ.)]

\title{
WAGES IN THE REPUBLIC OF BELARUS: SOCIAL AND ECONOMIC EFFICIENCY
}

\section{Tatyana Dolinina ${ }^{1}$}

\author{
Authors affiliation: ${ }^{1}$ Belarusian State Technological University (Minsk, Belarus). \\ Corresponding author: Tatyana Dolinina (tdolinina@mail.ru).
}

ABSTRACT. The paper distinguishes between the categories «wages» and «labor remuneration». Labor remuneration is defined as a process, with its functions identified. Wages is the result of this process, and they act in the form of cash flow, which performs a number of functions in the national economy. With regard to statistical and sociological indicators, there was assessed the implementation of wages' and labor remuneration's functions. There were identified social and economic problems of labor remuneration. Conclusions were draw non the necessity of labor remuneration reforming in the national economy of Belarus.

KEYWORDS: labor remuneration, wages, labor remuneration functions, functions of wages, labor remuneration reforming.

JEL-code: J31.

DOI: $10.46782 / 1818-4510-2020-2-60-78$ 